\title{
Análise Microbiológica da Água de Poço de Bairros da Cidade de Breu Branco-PA
}

\author{
Jezaías Silva Dos Santos (I), Rodrigo Cruz Nascimento (I), Flavio \\ Pedro De Lima (I), Lourival Marques Roland (I), Marcos De Sousa \\ Lima (I), Luciana Mendes Fernandes (I) \\ (I) IFPA - INSTITUTO FEDERAL DE EDUCAÇÃO, CIÊNCIA E TECNOLOGIA DO PARÁ (RUA \\ PORTO COLOMBO, 12 - VILA PERMANENTE-TUCURUÍ-PA - CEP . 68.455-695)
}

\section{Resumo}

A água é imprescindível para a manutenção da vida, pois possui diversos usos tanto para o homem (hidratação e preparo de alimento) e animais, quanto para a indústria, agricultura, transporte e lazer. Segundo a portaria No. 518 do Ministério da Saúde, água potável é aquela destinada ao consumo humano cujos parâmetros microbiológicos, físicos, químicos e radioativos atendam ao padrão de potabilidade e que não ofereça riscos à saúde. Para atendimento aos padrões microbiológicos exigidos pela mesma, quantifica-se um grupo de bactérias chamados coliformes, constituído de microrganismos de origem fecal e não-fecal, os coliformes totais e termotolerantes, respectivamente. Sua identificação na água pode indicar a existência de microrganismos de origem fecal na mesma. Neste sentido, o presente trabalho tem como principal objetivo avaliar microbiologicamente a água de poços rústicos em bairros do município de Breu Branco/PA, sendo coletada uma (01) amostra por bairro, totalizando dez bairros. Para a determinação dos coliformes totais e termotolerantes presentes na água analisada, utilizou-se a técnica do Número Mais Provável (NMP), cujas etapas consistiram em: teste presuntivo (caldo LST - Caldo Lauril Sulfato Triptose), teste confirmativo para coliformes totais (caldo VB - Caldo Verde Brilhante) e teste confirmativo para coliformes fecais/termotolerantes (caldo EC - Caldo Escherichia Coli). Seis amostras $(60 \%)$ foram positivas para coliformes totais apresentando valores entre

\footnotetext{
Referência:

Jezaías Silva Dos Santos, Rodrigo Cruz Nascimento, Flavio Pedro De Lima, Lourival Marques Roland, Marcos De Sousa Lima, Luciana Mendes Fernandes. Análise Microbiológica da Água de Poço de Bairros da Cidade de Breu Branco-Pa. In: Anais do 12 Congresso Latinoamericano de Microbiologia e Higiene de Alimentos - MICROAL 2014 [= Blucher Food Science Proceedings, num.1, vol.1]. São Paulo: Editora Blucher, 2014. 
0,91 NMP/ml e $16 \mathrm{NMP} / \mathrm{ml}$. Duas amostras (20\%) foram positivas para coliformes termotolerantes com valores de $0,36 \mathrm{NMP} / \mathrm{ml}$ e $0,91 \mathrm{NMP} / \mathrm{ml}$, mostrando-se fora dos padrões estabelecidos por conterem coliformes de origem fecal. Quatro bairros apresentaram resultado negativo com valor $<0,3 \mathrm{NMP} / \mathrm{ml}$ para ambos os parâmetros, coliformes total e fecal, estando em conformidades com os padrões estabelecidos pela portaria No $518 / 2004$. Conforme as análises obtidas, sugere-se um tratamento adequado da água para o consumo humano nos bairros analisados, bem como medidas sanitárias e de higiene.

Palavras-Chave: Água, Coliformes, Breu Branco

Agência de Fomento: 